\title{
UTICAJ POVEĆANE TJELESNE TEŽINE ZA NASTANAK KRVNOG PRITISKA (ARTERIJSKE HIPERTENZIJE)
}

\section{Sažetak}

Danas je debljina jedan od najvažnijih javno-zdrastvenih problema, koja ima globalni karakter epidemijskih razmjera u cijelom svijetu. Prevalencija debljine od 10-40\% u značajnom je porastu širom Europe. Povećanja oboljenja gojaznih osoba od arterijske hipertenzije znatno se povećavaju i materijalni troškovi u ostvarivanju zdravstvene zaštite (liječenja, rehabilitacije, naknade za trajni invaliditet). Analizirani su kartoni Opće službe Doma zdravlja Velika Kladuša u okviru edukacije PAT programa, oboljelih od hipertenzije starosne dobi pacijenata od 19. do 65. godina života, postavljena je hipoteza da se dokaže "da li postoji uzročno-posljedična veza između povišenog BMI-a i arterijske hipertenzije kao oboljenja".

Istraživačka hipoteza: BMI (Body mass index) veći od 27, direktno je povezan sa povišenjem krvnog tlaka i razvoja oboljenja kao što je arterijska hipertenzija.

Nulta hipoteza: BMI (Body mass index) kao odabrani senzor za arterijsku hipertenziju, nema nikakvog uticaja na kardiovaskularni sistem $i$ ne dovodi do povišenja krvnog tlaka. Hipotezu smo formulirali metodom uzajamne varijacije, tj. povišen indeks tjelesne mase na jednoj i arterijska hipertenzija na drugoj strani.

U Općoj službi Doma zdravlja Velika Kladuša, evidentirano je za 2010. godinu 1626 pacijenata oboljelih od arterijske hipertenzije sa različitim indeksom tjelesne mase BMI. Stopa morbiditeta za arterijsku hipertenziju u 2010. godini iznosi 54,2\%. Prosječan BMI iznosi 33,2 (srednja aritmetička sredina) što je signifikantno odstupanje dobijenog rezultata od zadanog "zlatnog standarda" koji iznosi 22. Vrijednost $X^{2}$ kvadrat testa od 4,2 u unaprijed odabranom nivou signifikantnosti $p=0,05$ uz stepen slobode od $1 \quad(N-1=1)$, direktno je potvrđena istraživačka hipoteza. U razumijevanju gojaznosti, povišenog BMI-a i arterijske hipertenzije kao vodećeg

\footnotetext{
${ }^{1}$ Visoka zdravstvena škola Univerziteta u Bihaću
} 
masovnog nezaraznog oboljenja važno je znati da su socijalnoekonomski, kulturni, biološki i genetički faktori oduvijek bili važni u određivanju $i$ unosa $i$ trošenja energije. Zajedno $s$ pušenjem, stresovima, pretjeranom konzumacijom alkohonih pića $i$ nedovoljnom tjelesnom aktivnosti, gojaznost pripada u grupu riziko faktora koji povećavaju smrtnost od nezaraznih bolesti, kao što su bolesti srca $i$ krvnih žila, šećerna bolest, bolest disajnih organa $i$ mnoge druge. Većina tih oboljenja povezana je s ekonomskim razvojem, životnim stilom, kao što je npr. nepravilna ishrana, i starenjem, a često se mogu spriječiti uvođenjem prijedloga mjera kroz: A. Ciljeve politike. $B$. Kontrolu radnog procesa.

Ključne riječi: debljina, hipertenzija, kardiovaskularne bolesti, BMI.

\section{UVOD}

Debljina je hronična bolest koja poprima epidemijske razmjere i prema podacima Svjetske zdravstvene organizacije postaje vodeći problem javnog zdravstva u 21. stoljeću. Alarmantni su podaci da $u$ razvijenim zemljama od gojaznosti boluje gotovo trećina odraslog stanovništva i čak petina djece. Ona se javlja kada je energetski unos mnogo veći od energetske potrošnje (fiziološke funkcije, fizička aktivnost). Trenutne procjene su da preko 300000 ljudi godišnje umre od gojaznosti i njom izazvanim komplikacijma. Sjedenje na radnom mjestu ključno je za epidemiju pretilosti. Jednom stvorenu masnu ćeliju vrlo je lako napuniti mašću, ali je teško eliminisati mast iz nje. Jedan kilogram masti daje oko 7000 suvišno unesenih kalorija.

Osobe sa povećanom tjelesnom težinom češće obolijevaju od sljedećih bolesti: povećanja krvnog pritiska, srčanih bolesti (infarkta i angine pektoris), šećerne bolesti, masnoća u krvi (holesterola i triglicerida), raka (crijeva, dojke, prostate) i degenerativnih bolesti zglobova (osteoartritis).

Posljedice debljine mogu biti: bolovi u zglobovima i leđima, gubitak daha već pri najmanjem naporu, povećano znojenje, pojava žučnih kamenaca, proširene vene i teškoće sa disanjem u snu (hrkanje). Pri povećanju tjelesne težine dolazi do naglog povećanja 
rizika od smrtnosti. Znači, što čovjek ima veću tjelesnu težinu, to je opasnost od prerane smrti veća.

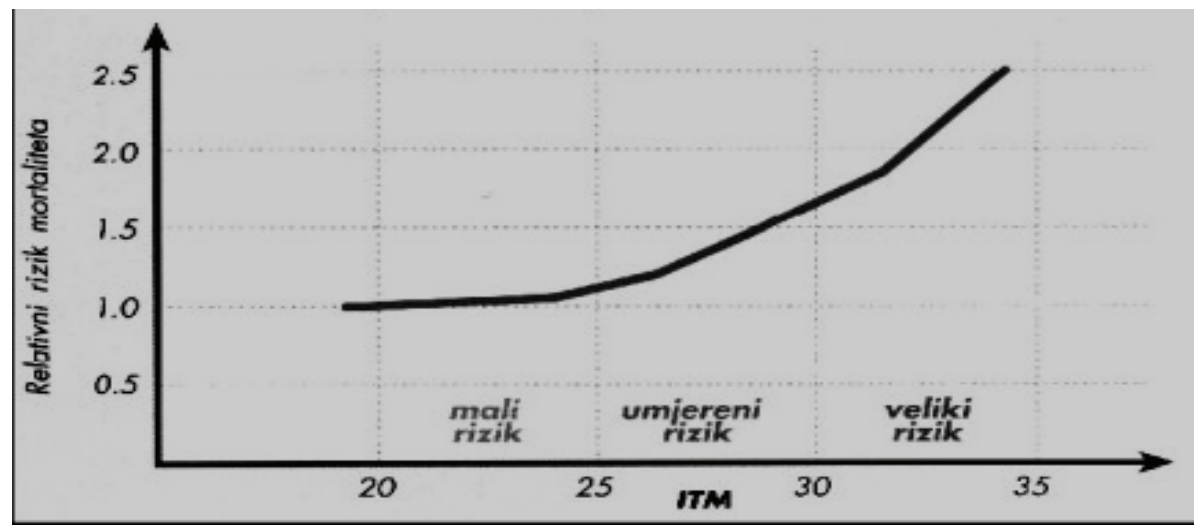

Grafikon 1. Odnos indeksa tjelesne mase prema relativnom riziku mortaliteta (smrtnosti)

ITM*: indeks tjelesne mase

\section{Etiologija nastanka debljine}

Očigledno je da postoje brojni i različiti faktori koji uzrokuju debljinu. Jedan od najčešćih je sasvim sigurno unos kalorijski bogate hrane u organizam. Užurbani način života, neredovni obroci i često uzimanje tzv. "brze hrane-fast food" još su neki od faktora, koji pridonose nakupljanju suvišnih kilograma. Rizični faktor predstavlja i nedovoljna i neredovna fizička aktivnost, odnosno vježbanje. Kada tijelo na taj način ne uspije potrošiti suvišne kalorije, one se jednostavno pohrane u obliku masti. Kao i kod brojnih drugih bolesti, genetika i kod debljine ima značajnu ulogu. Ponekad i psihološki faktori mogu uzrokovati pojavu debljine. Za mnoge ljude jelo predstavlja oblik borbe protiv tuge, ljutnje ili čak dosade. Također, i životna dob je bitan faktor za povećanje debljine. Godine nose sa sobom povećanje masnih depoa i smanjenje mišićne mase. To se posebno odnosi na žene, zbog manjka mišićne mase, koja se nadoknađuje s mašću. Mnogo faktora utiče na pojavu debljine: genetički, faktori okoline, neurološki i psihološki, biohemijski i kulturološki i psihosocijalni faktori.

U posebnu grupu dolaze medicinski faktori: neliječena hipotireoza, Cushingov sindrom i hipotalamička debljina. 
Konzumiranje hrane preko potreba za $1 \%$ daje višak od 10000 $\mathrm{kcal} /$ godišnje ili višak od 1-2 kg.

Zdravstvene posljedice debljine su: povećanje obolijevanja i smrtnosti, smanjena produktivnost, povećani troškovi zdravstvene zaštite, socijalne i ekonomske posljedice.

Debljina je faktor rizika za mnoge bolesti, tj. debele osobe lakše obolijevaju od slijedećih bolesti: srčane bolesti, šećerna bolest, visok krvni pritisak, povećane masnoće, moždani udar, otežano disanje u snu, degenerativne bolesti, pojava raka, žučni kamenci i ginekološki poremećaji.

Mnoge bolesti su povezane sa debljinom. Srčane bolesti vrlo često su uzrokovane i potencirane kod gojaznih osoba. Prema Framingamskoj studiji, definisana je opasnost od debljine, koja je gotovo identična opasnosti za zdravlje koja prijeti od pušenja. Porast tjelesne težine zahtijeva pojačan rad srca, koje mora opskrbiti višak tkiva s krvlju. Pojačan rad srca postiže se povećanjem krvnog pritiska i zapremine krvi, što dovodi do povećanja i proširenja srčanog mišića u lijevoj komori. Debljina izuzetno opterećuje fiziologiju srca. Poznato je da $1 \mathrm{~kg}$ viška masnoća traži od srca dodatnih 4000 metara krvnih žila. Upravo je ovo značajan faktor rizika za nastanak nagle smrti, ali i drugih srčanih bolesti i komplikacija. Pouzdano je dokazano da je inzulinska rezistencija početni poremećaj, koji dovodi do povećanog krvnog pritiska i povećanja masnoća u krvi. Inzulinska otpornost/rezistencija ima ključnu ulogu u vezi debljine i nastanka šećerne bolesti, kao i povećanja krvnog pritiska. Glavna karakteristika inzulinske otpornosti jeste smanjenje ulaska šećera u mišiće $i$ povećano stvaranje masti. Poremećaji koji proizilaze iz debljine su nazvani "smrtonosni kvartet". Rizik osobe sa visokim krvnim pritiskom za nastanak moždanog udara je 7 puta veći nego kod populacije sa normalnim pritiskom. Mnoge studije pokazuju da se kod mlađih osoba od 20-40 godina, visok krvni pritisak javlja 6 puta češće kod debelih, nego kod njihovih vršnjaka normalne tjelesne težine/mase.

Kada govorimo o spriječavanju nastanka te bolesti, mislimo u prvom redu o uklanjanju rizika za nastanak debljine, a to je u prvom redu ishrana. Epidemiološke studije pokazuju povezanost debljine i porasta masnoća u krvi. Svako odstupanje od normalnog režima 
ishrane dovodi u pitanje i normalno odvijanje metaboličkih funkcija $\mathrm{u}$ organizmu čovjeka. Poznato je da je ishrana stanovništva danas raznovrsna, da je praćena deficitom ili suficitom njenih gradivnih komponenti neophodnim za održavanje psiho-fizičke harmonije u našem organizmu. Svaka inkompatibilnost tih gradivnih komponenti se najčešće manifestuje kroz različita oboljenja. Naši preci najčešće nisu imali problema s debljinom-nije bilo dovoljno hrane za debljanje, a samo održavanje života zahtijevalo je dosta tjelesnog napora. Prekomjerna tjelesna težina rezultat je djelovanja mnogih faktora, od genetskih do načina ponašanja i odnosa sa okolišnim faktorima. Gojaznost nije problem koji se javlja iznenada, ona se razvija tokom nekog razdoblja, pa je s toga vremenom moguće i smršaviti što se, identično dešava u većini slučajeva i sa arterijskom hipertenzijom kao vodećim masovnim nezaraznim oboljenjem.

Nema nikakve sumnje da je gojaznost ozbiljna bolest koja izaziva mnoge kliničke komplikacije, zbog čega se smanjuje kvalitet života, radna sposobnost i ono što je najbitnije - skraćuje životni vijek. Direktni i indirektni troškovi liječenja kako debljine tako i povećanog krvnog tlaka veliki su teret za proračune zdravstvenih sistema. Teško je mjeriti, kvantificirati, koliko se masnoće nalazi u organizmu čovjeka. Ali, gojaznost je mjerena na više različitih načina, uvođenje indeksa tjelesne mase (BMI-body mass indeks ili Queletov indeks) pridonijelo je mnogim za dobrobit čovječanstva važnim epidemiološkim istraživanjima i upoređivanjima između različitih populacija u svijetu.

Široko prihvaćena metoda procjene gojaznosti je izračunavanje tzv. BMI-a (body mass indeks). Izračunava se tako da se masa tijela u kilogramima podijeli sa tjelesnom visinom u metrima na kvadrat.

\section{BMI $=\mathbf{k g} / \mathbf{m}^{2}$}

Poželjna tjelesna težina je između 18,5 i 25 , rezultati manji od 18,5 označavaju pothranjenost a iznad 25 gojaznost. Normalno uhranjena osoba ima tjelesnu masu u rasponu od 80 do $120 \%$ poželjne tjelesne težine. BMI je, kao senzor arterijske hipertenzije, za muškarce i žene između 19. i 34. godine života između 20 i 25 , a za starije od 35 godina života između 22 i 27. 
Tabela 1. Klasifikacija povećane tjelesne težine i gojaznosti u odraslih s obzirom na BMI i rizik nastanka komplikacija ( Prema preporuci WHO iz 1997.)

\begin{tabular}{|c|c|c|c|}
\hline KLASIFIKACIJA & BMI & $\begin{array}{c}\text { TJELESNA } \\
\text { TEŽINA }\end{array}$ & RIZIK \\
\hline Pothranjenost & Ispod 18,5 & $\begin{array}{c}\text { Mali, ali } \\
\text { Ispod } 80 \%\end{array}$ & $\begin{array}{l}\text { postoji opasnost } \\
\text { od drugih } \\
\text { kliničkih } \\
\text { poremećaja }\end{array}$ \\
\hline $\begin{array}{c}\text { Normalna } \\
\text { tjelesna masa }\end{array}$ & $18,5-24,9$ & $80-120 \%$ & Prosječan \\
\hline $\begin{array}{c}\text { Povećana } \\
\text { tjelesna masa }\end{array}$ & $25,0-29,9$ & $+20-30 \%$ & $\begin{array}{c}\text { Nešto } \\
\text { povećan }\end{array}$ \\
\hline Gojaznost: Iznad 30,0 & $30,0-34,9$ & $+30-55 \%$ & Umjeren \\
\hline I. stepen & $35,0-39,0$ & $+55-80 \%$ & Velik \\
\hline II. stepen & Iznad 40,0 & + iznad $80 \%$ & Vrlo velik \\
\hline III. stepen & &
\end{tabular}

Postoji još jedna posebno jednostavna metoda utvrđivanja povećanja tjelesne težine, a vrši se mjerenjem obima struka. Smatra se da normalan obim struka ne bi trebao prelaziti $80 \mathrm{~cm}$ za žene, a $94 \mathrm{~cm}$ za muškarace.

Slika 1. Mjerenje, utvrđivanje debljine

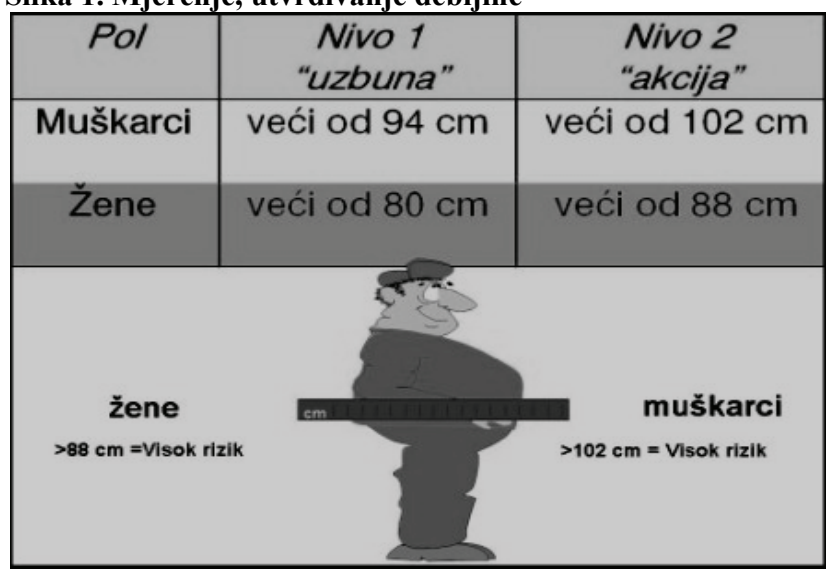




\section{FORMULACIJA PROBLEMA}

Debljina (Obesistas) povećava mortalitet i morbiditet, posljedica je nastanaka arterijske hipertenzije, i ta skupina ljudi svrstava se $u$ rizičnu skupinu.

Zbog povećanja oboljevanja gojaznih osoba od arterijske hipertenzije znatno se povećavaju i materijalni troškovi u ostvarivanju zdravstvene zaštite (liječenja, rehabilitacije, naknade za trajni invaliditet).

\section{HIPOTEZA}

Prateći i analizirajući medicinske zdravstvene kartone Opće službe Doma zdravlja Velika Kladuša u okviru edukacije PAT programa, starosne dobi pacijenata od 19. do 65. godine života postavljena je hipoteza da dokaže "da li postoji uzročno-posljedična veza između povišenog BMI-a $i$ arterijske hipertenzije kao oboljenja".

Za "zlatni standard" odabrana je vrijednost BMI-a od 22, u kontroli radnog procesa pokazali bismo koliko smo blizu ili daleko od "zlatnog standarda", a što ujedno nameće i revizijsko pitanje: "Dobrog primjera kontinuiteta njege, skrininga i zdravstvenog prosvjećivanja dotičnih pacijenata?" ( eng. AUDIT- revizija).

ISTRAŽIVAČKA HIPOTEZA: BMI (Body mass index) veći od 27 direktno je povezan sa povišenjem krvnog tlaka i razvoja oboljenja kao što je arterijska hipertenzija.

NULTA HIPOTEZA: BMI (Body mass index) kao odabrani senzor za arterijsku hipertenziju nema nikakvog uticaja na kardiovaskularni sistem i ne dovodi do povišenja krvnog tlaka.

Hipotezu smo formulirali metodom uzajamne varijacije, tj. povišen indeks tjelesne mase na jednoj i arterijska hipertenzija na drugoj strani. 


\section{CILJEVI ISTRAŽIVANJA}

Da se utvrdi povezanost povećanog BMI za nastanak i razvoj arterijske hipertenzije kod stanovništva u dobi od 19. do 65. Godina, cilj bi trebao da apsolutno opravda istraživačku hipotezu.

Da se shodno rezultatima, a na osnovu kontrole radnog procesa tj. revizije prakse, iznađu što bolji ciljevi srednjoročne politike na poboljšanju normi, odluka, operacija, koje će zasigurno trebati sprovesti, da bi se došlo do zadanog "zlatnog standarda", a u smjeru što boljih rezultata.

\section{METODOLOGIJA RADA}

U svrhu istraživanja su praćeni pacijenti starosne dobi od 19. do 65. godina oboljelih od arterijske hipretenzije čiji broj iznosi u Općoj službi Doma zdravlja Velika Kalduša 1626 za 2010. godinu. Za varijablu grupisanu u razrede odabran je - indeks tjelesne mase (BMI) kojeg ću u rezultatima istraživanja komparirati sa izabranim "zlatnim standardom" vrijednosti od 22. Postupak za prikupljanje informacija o radnom procesu i njegovom učinku ili možda neučinku za istu grupu ispitanika je upravo BMI. Statistička obrada koja je urađena i prezentirna, bazirana je na prostoru posmatranja Općine Velika Kladuša, sa ukupnim brojem stanovnika. kako urbanog tako i ruralnog područja od 30.000 (slobodna procjena). Te bi stopa morbiditeta oboljelih od arterijske hipertenzije za 2010. godinu izgledala ovako:

1626

Stopa morbiditeta $=$----------------- x $100000=54,2 \%$

300000

Stopa morbiditeta za arterijsku hipertenziju u 2010. godini iznosi $54,2 \%$.

U Općoj službi Doma zdravlja Velika Kladuša evidentirano je za 2010. godinu 1626 pacijenata oboljelih od arterijske hipertenzije sa različitim indeksom tjelesne mase BMI. 


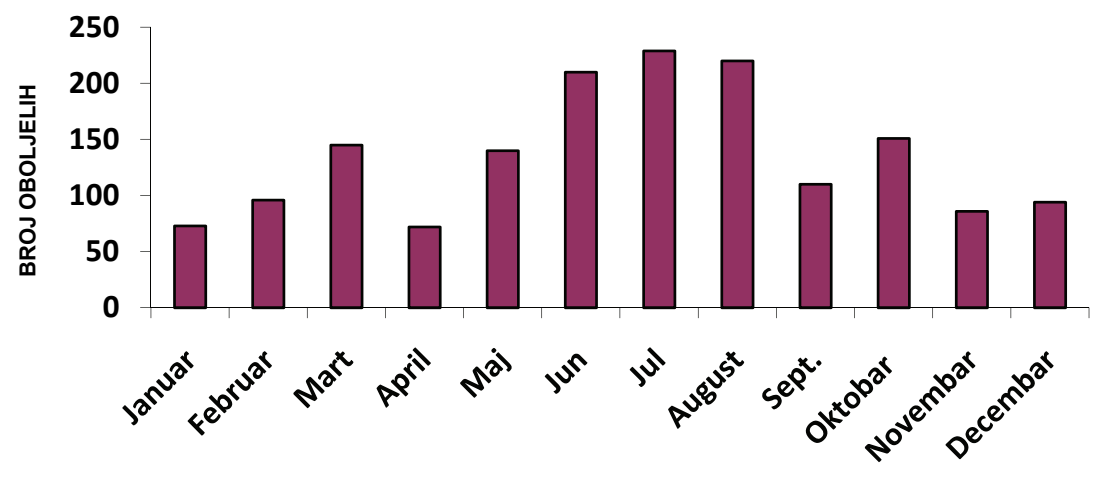

ZA 2010. GODINU

Grafikon 2. Morbidite (bolest) i broj oboljelih

Shema 1. Izračunavanje srednje aritmetičke sredine iz podataka grupiranih u razrede

\begin{tabular}{|c|c|c|c|}
\hline $\begin{array}{l}\text { Varijable } \\
\text { grupisane } \\
\text { razrede (BMI) }\end{array}$ & $\begin{array}{c}\text { Sredina } \\
\text { razreda } \\
(\mathrm{X}) \\
\mathrm{X}_{1}+\mathrm{X}_{2} / 2\end{array}$ & $\begin{array}{c}\text { Broj } \\
\text { pacijenata } \\
(\mathrm{N})\end{array}$ & $\begin{array}{c}\text { Ponderisana } \\
\text { sredina } \\
(\mathrm{fx}) \\
\mathrm{X} \times \mathrm{x}\end{array}$ \\
\hline $18-20$ & 19 & 73 & 1387 \\
\hline $21-23$ & 22 & 96 & 2112 \\
\hline $24-26$ & 25 & 175 & 4375 \\
\hline $27-29$ & 28 & 182 & 5096 \\
\hline $30-32$ & 31 & 210 & 6510 \\
\hline $33-35$ & 34 & 229 & 7786 \\
\hline $36-38$ & 37 & 220 & 8140 \\
\hline $39-41$ & 40 & 196 & 7840 \\
\hline $42-44$ & 43 & 151 & 6493 \\
\hline $45-47$ & 46 & 94 & 4324 \\
\hline & & $\mathbf{U k m p n o}$ & Suma 54063 \\
\cline { 3 - 4 } & & $\mathbf{1 6 2 6}$ &
\end{tabular}

$$
\begin{gathered}
\sum \mathrm{fX} \\
\mathrm{X}=\mathrm{-}
\end{gathered}
$$


Prosječan BMI iznosi 33,2 što je već iz izračunavanja srednje aritmetičke sredine signifikantno odstupanje od dobijenog rezultata od zadanog "zlatnog standarda" koji iznosi 22.

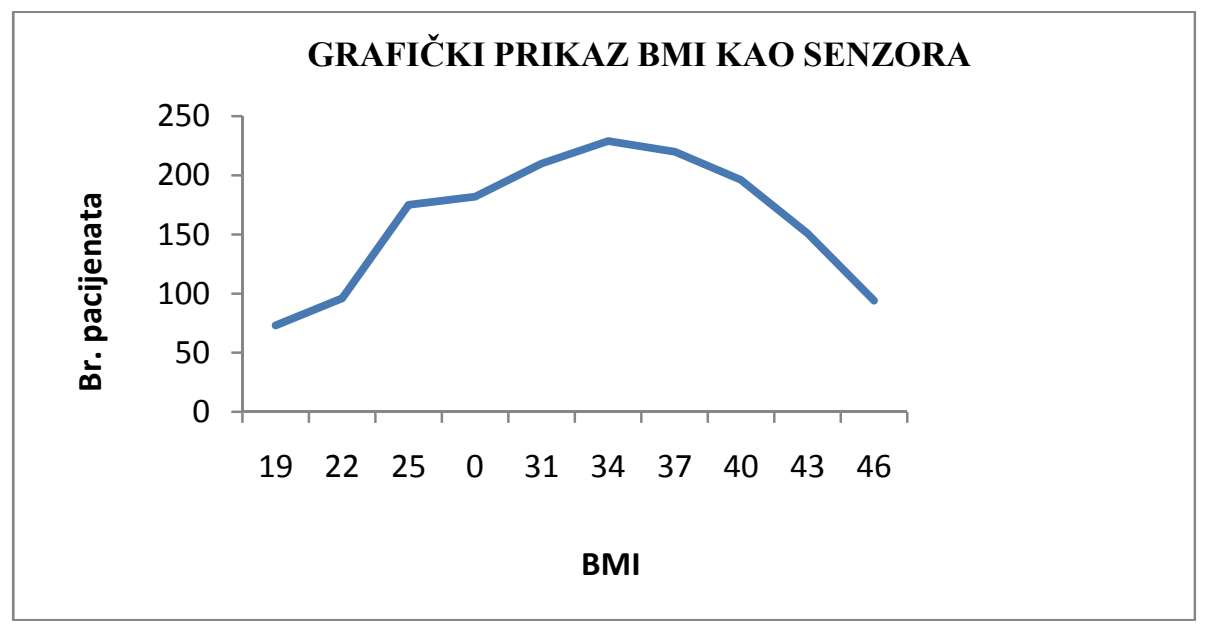

Grafikon 3. Grfički prikaz BMI i broj pacijenata

Za statističku obradu uzeto:

1. broj pacijenata koji iznosi 1626 ,

2. srednju aritmetičku vrijednost za BMI koja iznosi 33,2

Standardna devijacija koja nam govori koliko svaki član $\mathrm{u}$ statističkom nizu plus ili minus odstupa od aritmetičke sredine, odnosno od vrijednosti "zlatnog standarda", da bi se potvrdio cilj ovog istraživanja.

STAD .DEVIJACIJA $(\sigma)= \pm \sqrt{\frac{\varepsilon f *(x-\bar{x})^{2}}{N}}$

\begin{tabular}{|l|l|l|}
\hline $\mathbf{X}$ & $\mathbf{F}$ & $\overline{(\mathbf{X}-\mathbf{X})^{\mathbf{2}} \mathbf{x ~ f}}$ \\
\hline 19 & 73 & 14718 \\
\hline 22 & 96 & 12042 \\
\hline 25 & 175 & 11767 \\
\hline 28 & 182 & 4921 \\
\hline 31 & 210 & 1016 \\
\hline 34 & 229 & 146 \\
\hline 37 & 220 & 3176 \\
\hline 40 & 196 & 9063 \\
\hline
\end{tabular}




\begin{tabular}{|l|c|c|}
\hline 43 & 151 & 14502 \\
\hline 46 & 94 & 15400 \\
\hline Ukupno & $\mathbf{1 6 2 6}$ & $\mathbf{8 6 7 5 2}$ \\
\hline
\end{tabular}

$\sigma= \pm \sqrt{53,35} \sigma= \pm 7,3$

Ovaj rezultat nam ukazuje upravo na odstupanje svakog člana u statističkom nizu od srednje aritmetičke sredine u iznosu od $\pm 7,3$. To je upravo i pokazatelj uzročno-posljedične veze BMI-a i arterijske hipertenzije kao oboljenja.

Za testiranje postavljene istraživačke hipoteze, za određivanje signifikantnosti dobivenih rezultata da povišen indeks tjelesne mase direktno utiče na pojavu oboljenja kao što je arterijska hipertenzija koristen je $X^{2}$-kvadrat testom, koji i služi za utvrđivanje razlike između opaženih i očekivanih frekvencija.

\begin{tabular}{|c|c|l|l|r|r|}
\hline $\begin{array}{l}\text { Rezultati } \\
\text { BMI-a }\end{array}$ & \multicolumn{1}{l|}{ O } & \multicolumn{1}{l|}{ E } & \multicolumn{1}{l|}{ O-E } & ${\text { ( O-E })^{\mathbf{2}}}^{\left(\underline{\mathbf{O}-E}^{\mathbf{2}}\right.}$ \\
\hline $18-27$ & 730 & 813 & -83 & 6889 & $\mathbf{4 , 2}$ \\
\hline $28-47$ & 896 & 813 & 83 & 6889 & $\mathbf{4 , 2}$ \\
\hline
\end{tabular}

Vrijednost $X^{2}$ kvadrat testa od 4,2 na nivou signifikantnosti $\mathrm{p}=$ $0,05 \mathrm{uz}$ stepen slobode od $1(\mathrm{~N}-1=1)$, potvrđena je istraživačka hipoteza.

\section{REZULTATI ISTRAŽIVANJA}

U realizaciji polaznih ciljeva praćen je uticaj indeksa tjelesne mase (BMI) kao senzora odgovornog za nastanak arterijske hipertenzije. Rezultat istrživanja ukazuje da je vrijednost BMI-a veća od 27 direktni uzrok pojave arterijske hipertenzije kao oboljenja, a ne samo kao riziko faktor $\mathrm{u}$ nastanku istog.

\section{DISKUSIJA}

Gojaznost je bolest koja predstavlja kronični problem koji zahtijeva doživotno liječenje poput arterijske hipertenzije, šećerne bolesti ili bronhalne astme. Gojaznost se liječenjem može nadzirati, ali se ne može liječiti. Najčešće medicinske posljedice gojaznosti i 
povišenih vrijednosti BMI-a kao odgovornog za isto oboljenje prikazan je na tabeli 2 .

Tabela 2. Medicinske posljedice gojaznosti

\begin{tabular}{|c|c|c|}
\hline MEHANIČKE & METABOLIČKE & $\begin{array}{r}\text { MEHANIČKE } \\
\text { METABOLIČKE }\end{array}$ \\
\hline Bol u leđima & $\begin{array}{l}\text { Rezistencija na } \\
\text { inzulin }\end{array}$ & Hipertenzija \\
\hline $\begin{array}{l}\text { Ozljede na radnom } \\
\text { mjestu }\end{array}$ & Šećerna bolest tipa 2 & Dispneja \\
\hline $\begin{array}{c}\text { Stresna } \\
\text { inkontinencija }\end{array}$ & $\begin{array}{l}\text { Smanjena tolerancija } \\
\text { glukoze }\end{array}$ & Varikoziteti vena \\
\hline Intertrigo & Dislipidemije & Osteoartritis \\
\hline Edemi/celulitis & Koronarna bolest & Znojenje \\
\hline Dehiscijencija rana & Žučni kamenci & $\begin{array}{l}\text { Respiratorna } \\
\text { insuficijencija }\end{array}$ \\
\hline Hirzutizam & $\begin{array}{ll}\text { Apneja } & \text { tokom } \\
\text { spavanja } & \\
\end{array}$ & \\
\hline & $\begin{array}{c}\text { Ca. dojke, kolona, } \\
\text { prostate }\end{array}$ & \\
\hline & $\begin{array}{l}\text { Poremećaj menstrual. } \\
\text { ciklusa }\end{array}$ & \\
\hline & Infertilitet & \\
\hline
\end{tabular}

\section{ZAKLJUČAK}

U razumijevanju gojaznosti, povišenog BMI-a i arterijske hipertenzije, kao vodećeg masovnog nezaraznog oboljenja, važno je znati da su socijalno-ekonomski, kulturni, biološki i genetički faktori oduvijek bili važni u određivanju i unosa i trošenja energije.

Zajedno s pušenjem, stresovima, pretjeranom konzumacijom alkohonih pića i nedovoljnom tjelesnom aktivnosti, gojaznost pripada u grupu riziko faktora koji povećavaju smrtnost od nezaraznih bolesti kao što su bolesti srca i krvnih žila, šećerna bolest, bolest disajnih organa i mnoge druge. Većina tih oboljenja povezana je $\mathrm{s}$ ekonomskim razvojem, životnim stilom (nepravilna ishrana, alkohol, duhan, droge) često se mogu spriječiti uvođenjem prijedloga mjera kroz:
A) Ciljeve politike
B) Kontrolu radnog procesa 
Gojaznost i arterijska hipertenzija negativno utiču na sve životne okolnosti kao što su: rad, rekreacija, socijalni i interpersonalni odnosi. Oboljeli pod dijagnozom arterijske hipertenzije i gojaznosti ne mogu raditi i doprinositi društvenoj zajednici zbog niza problema koji utiču na kvalitetu života i rada. Takve osobe su usamljene, zaboravljene i nezaposlene. Diskriminacija je česta, i to ne samo zbog izgleda nego i zbog jače svijesti o tome da je takvim osobama ugroženo zdravlje.

\section{A) Ciljevi politike}

Program i njegova operativnost bi se temeljila na:

- mjerenju tjelesne težine, tjelesne visine te izračunavanja BMI-a od strane medicinske sestre koristeći istu standardizovanu aparaturu za ovu vrstu senzora

- mjerenju krvnog tlaka uvijek na istom aparatu (tlakomjer) od strane medicinske sestre pacijentu prije ulaska kod ljekara (stres).

- promjeni životnih navika

- redukcijskoj dijeti

- povećanoj fizičkoj aktivnosti

- prakticirati 1x mjesečno od strane ljekara da radi na promociji zdravlja oboljelih i neoboljelih od arterijske hipertenzije u trajanju od 2 sata kao i provođenje skrining testova kroz odabrani senzor kao npr. BMI.

- savjet o pravilnoj prehrani i tjelesnoj vježbi je vrlo bitan u početku liječenja. Pažljiviji izbor namirnica i tjelesna aktivnost kao što je npr. " BRISK WALKING " - žustro hodanje 20 minuta dnevno smanjuju rizik za kardio-vaskularna oboljenja za $20 \%$, još su najbolji i najzdraviji način gubitka prekomjerne težine, a shodno tome i održavanju krvnog tlaka u referentnim vrijednostima.

- u liječenju gojaznosti i arterijske hipertenzije potrebno je prilagoditi stajališta onih koji se liječe i njihovih liječnika, a ne samo se bazirati na propisivanje lijekova za hipertenziju.

- u slučaju neuspjeha ili nedovoljnim tretmanom životnog stila, potrebno je primijeniti farmakoterapiju. 


\section{B) Kontrola radnog procesa (rada u ambulantama)}

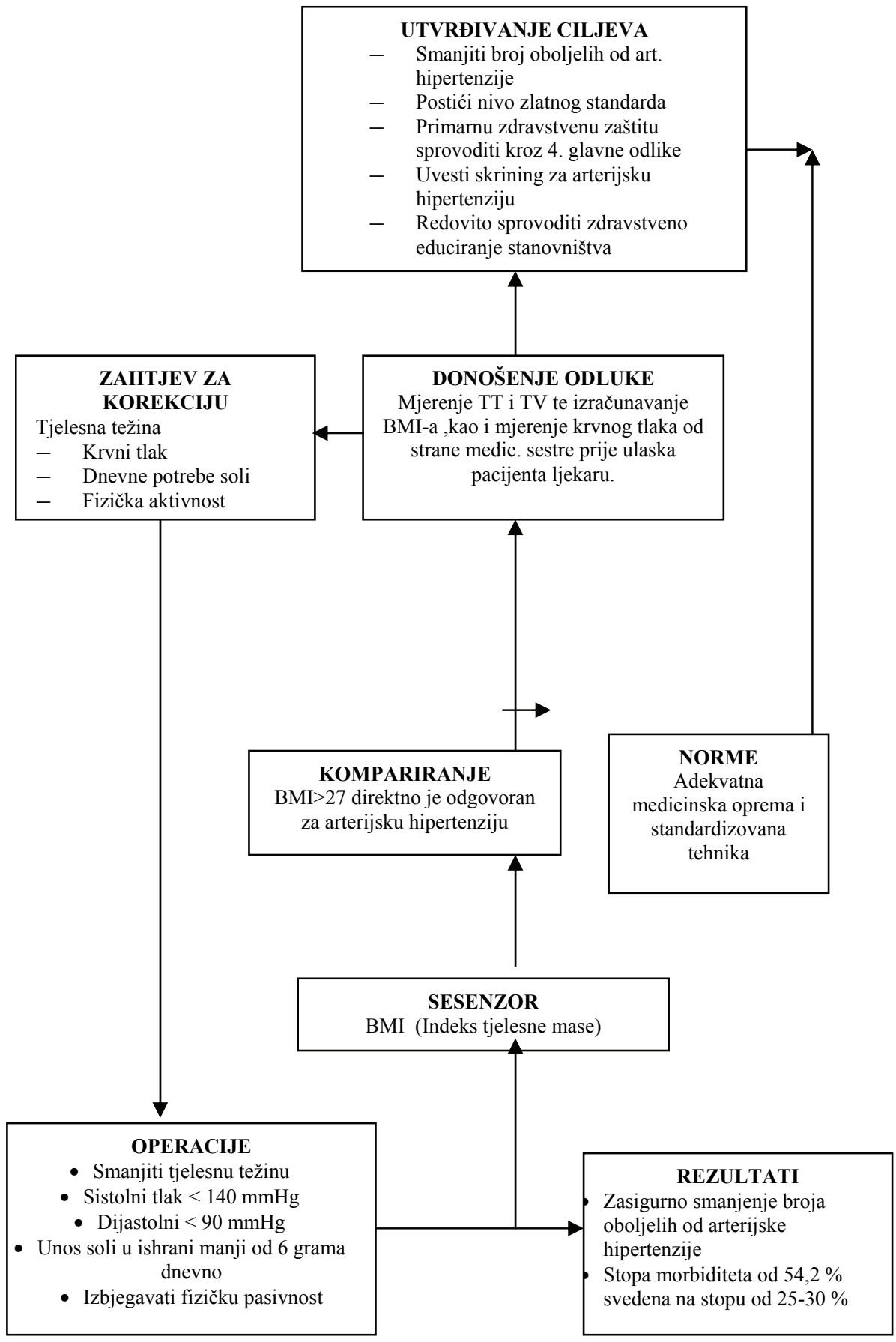




\section{AUDIT- DEFINICIJA REVIZIJE}

Navedene činjenice nameću zahtjev za uvođenjem tzv. internog audita, što bi značilo studiju nekog dijela medicinske prakse. Kakav je to kvalitet u pružanju zdravstvenih usluga? Da uporedimo rad u ambulantama sa "zlatnim standardom" tj. odabranim senzorom.

Ciklus revizije bi se sastojao u slijedećem:

- postaviti senzor koji mora imati svoju normu za praćenje zdravstvenog stanja,

- ocijeniti ljekarsku praksu-kakva je to praksa,

- kako se obavlja doktorska praksa, te je uporediti sa "zlatnim standardom",

- izvršiti identifikaciju prilika, tj. mjera za poboljšanje da bi došli do boljih rezultata.

Zadaci bi bili slijedeći:

- predložiti promjene

- sprovesti promjene

- ocijeniti promjene.

Mogu postojati barijere za promjene koja bi se sastojala u neshvatanju da postoji problem, otporu prema promjenama, strahu od promjena, finansijska i lična pitanja, nemotiviranosti na promjene, te regulacije unutar sistema.

Primarna zdravstvena zaštita bi trebala da bude okarakterizirana sa 4. glavne odlike:

1. da je njega pri prvom kontaktu pristupačna tj. dostupna za svakog pojedinca,

2. razumljivost njege - raznolikost usluga za sve članove porodice korisnike zdravstvene zaštite,

3. kontinuitet njege - duži vremenski period od strane istog ljekara i med. sestre (istog tima),

4. mora postojati koordinacija njege (po vertikali i horizontali).

Ove 4. odlike bi trebale da budu "zlatni standard" da bi se u kontroli radnog procesa što brže, sigurnije i jednostavnije došlo do boljih rezultata. Prevencija kroz edukaciju na svim razinama, kroz 
poticanje razvoja prehrambene, tjelesne i zdravstvene kulture, razvijanjem svijesti o važnosti poželjne tjelesne težine uz redovitu liječničku kontrolu (preventivne preglede), predstavlja najbolji i najjeftiniji način održavanja i postizanja zdravlja.

\section{Literatura:}

1. Graham I., Atar D, Borch-Johnsen K, Boysen G, Burell G, Cifkova R, Dallongeville J, De Backer G, Ebrahim S, Gjelsvik B, Herrmann-Lingen C, Hoes A, Humphries S, Knapton M, Perk J, Priori SG, Pyorala K, Reiner Ž, Ruilope L, Sans-Menendez S, Scholte Op Reimer W, Weissberg P, Wood D, Yarnell J, Zamorano JL. European practice guidelines on prevention of cardiovascular diseases: executive summary. G Ital Cardiol 2008; 9:11-59.

2. Jelaković B, Kuzmanić D, Miličić D, Reiner Ž, Aganović I, Bašić-Jukić N, Božikov J, Čikeš M, Dika Ž, Đelmiš J, Galešić K, Hrabak-Žerjavić V, Ivanuša M, Jureša V, Katić M, Kern J, Kes P, Laganović M, Pavlović D, Pećin I, Počanić D, Rački S, Sabljar-Matovinović M, Sonicki Z, Vrcić-Keglević M, Vuletić S, Zaputović L. Smjernice za dijagnosticiranje i liječenje arterijske hipertenzije. Praktične preporuke hrvatske radne skupine i osvrt na smjernice ESH/ESC 2007. Liječ Vjesn 2008;130:115-3.

3. Reiner Ž. Ateroskleroza i cerebrovaskularne bolesti. Liječ Vjesn 2008; 130 (Supl. 6): 14-17.

4. Reiner Ž. Ateroskleroza - najvažniji razlog smrtnosti u Hrvatskoj. U: Liječnici u trećoj dobi - Druga knjiga (ur. Kremzir D), Hrvatsko društvo umirovljenih liječnika HLZ, Zagreb 2008., str. 19-25.

5. Fruchart J-C, Sacks F, Hermans MP, Assmann G, Brown VW, Ceska R, Chapman MJ, Dodson PM, Fioretto P, Ginsberg HN, Kadowaki T, Lablanche JM, Marx N, Plutzky J, Reiner Ž, Rosenson RS, Smith Jr SC, Staels B, Stock JK, $\mathrm{PhD}$, Sy R, Wanner C, Zambon A, Zimmet P. The Residual Risk Reduction Initiative: A call to action to reduce residual vascular risk in dyslipidemic patients. A position paper by the Residual Risk Reduction Initiative (R3I). Diabetes Vasc Dis Res 2008; 4:319-35.

6. Bergovec M, Reiner Z, Miličić D, Vražić H. Differences in risk factors for coronary heart disease in patients from continental and Mediterranean regions of Croatia.. Wien Klin Wochenschr. 2008;120:684-692.

7. Fruchart JC, Sacks F, Hermans MP, Assmann G, Brown WV, Ceska R, Chapman MJ, Dodson PM, Fioretto P, Ginsberg HN, Kadowaki T, Lablanche JM, Marx N, Plutzky J, Reiner Z, Rosenson RS, Staels B, Stock JK, Sy R, Wanner C, Zambon A, Zimmet P. The Residual Risk Reduction Initiative: a call to action to reduce residual vascular risk in patients with dyslipidemia. Am J Cardiol. 2008;102:1K-34K. 
Sulejman Kendic, Ph d, Samir Poric, MA

\section{IMPACT OF OVERWEIGHT ON THE OCCURRENCE OF BLOOD PRESSURE (ARTERIAL HYPERTENSION)}

\section{SUMMARY}

Obesity is of one of the most important contemporary health problem, which has a global character of the epidemic measures worldwide. The prevalence of obesity of $10-40 \%$ is significantly increasing across Europe. Increase in the number of obese people who suffer from arterial hypertension, also significantly increases the material costs of health care (treatment, rehabilitation, compensation for permanent disability). We have analysed medical records from the General Services of the Hospital in Velika Kladuša during the PAT training program. Patients who suffer from Arterial Hypertension in the age from 19 to 65 were examined, and we have stated a Hypothesis ,whether there is a relationship of cause and effect between elevated BMI and Arterial Hypertension as a disease."

Research Hypothesis: BMI (Body Mass Index) greater than 27 is directly linked to the high blood pressure and development of diseases such as Hypertension.

The Null Hypothesis: BMI (Body Mass Index) as the selected sensor for arterial hypertension has no effect on the cardiovascular system and increased blood pressure. We formulate the Hypothesis by the method of mutual variations, i.e. elevated BMI on the one hand and Arterial Hypertension on the other side.

The General Services of the Hospital in Velika Kladuša recorded for the year 2010 a total of 1626 patients suffering from Arterial Hypertension with different body mass index - BMI.

Morbidity rate from Arterial Hypertension in the year 2010 amounted to $54.2 \%$. The average BMI was 33.2 (a middle arithmetic measure) which is a significant deviation from the default "gold standard", which is 22 . The research hypotheses were directly confirmed by the value of $\mathrm{X}^{2}$ square test of 4.2 in the pre-selected level of significance $\mathrm{p}=0.05$ with degree of freedom of $1(\mathrm{~N}-1=1)$. In the understanding of obesity, high BMI and Hypertension as the leading massnon-infectious disease it is important to know that the 
socio-economic, cultural, biological and genetic factors have always been important in determining both the intake and energy expenditure. Along with smoking, stress, excessive consumption of alcoholic drinks and insufficient physical activity, obesity belongs to a group of risk factors that increase mortality from non-infectious diseases such as cardiovascular diseases, diabetes, respiratory diseases and many others. Most of these diseases are associated with economic development and lifestyle, such as improper diet and aging. These diseases can often be prevented through the introduction of the proposed measures: A Objectives of the policy and B Control of the work process.

Keywords: obesity, Hypertension, cardiovascular disease, BMI 
الأستاذ الدكتور سليمان كينديتش وم. الطبيب سامر بوريتش

تأثير زيادة الوزن الجسمي على حدوث ضغط الدم (ارتفاع ضغط الدم الشرياني)

\section{خلاصة البحث}

أصبحت السمنة إحدى أهم الأمراض العامة ولها طابع عالمي وأبعاد الوباء في

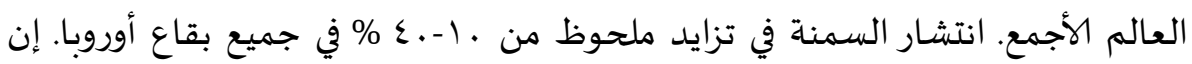

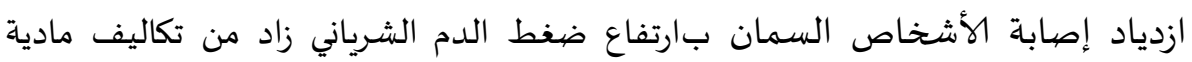

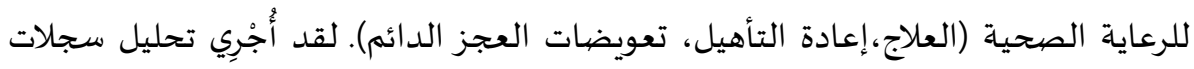

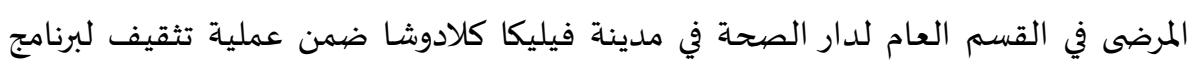

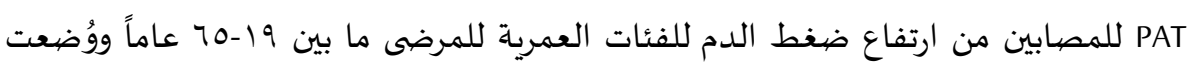

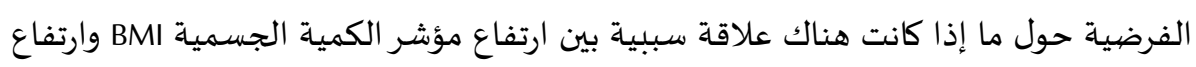

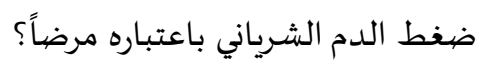
فرضية البحث: إن كان مؤشر الكمية الجسمية BMI (Body mass index)

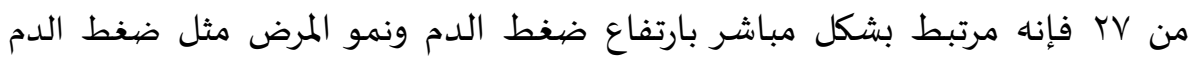
الشرياني

فرضية العدم: إنّ مؤشر الكمية الجسمية Body mass index) باعتباره

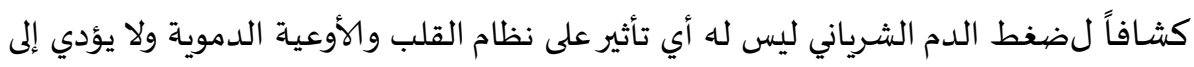

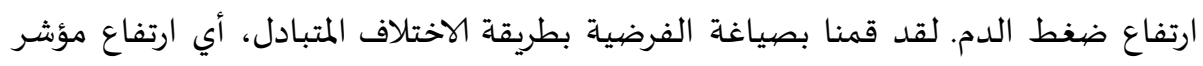

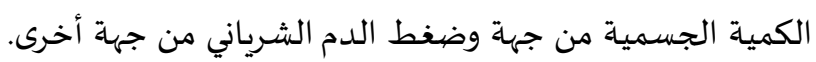

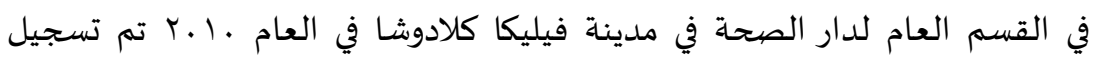

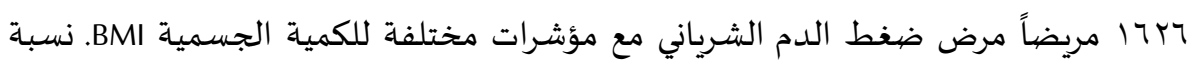

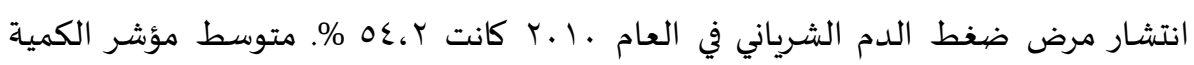

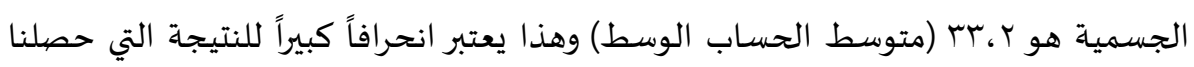

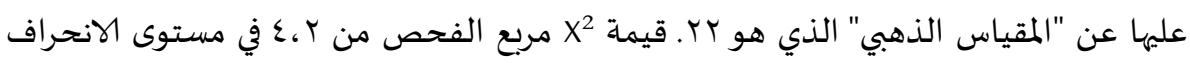

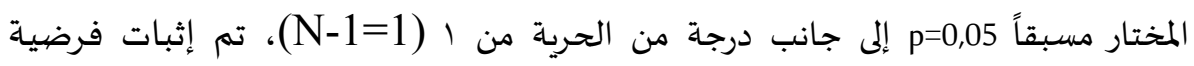

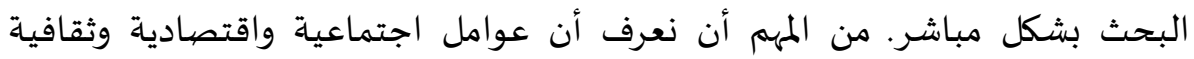

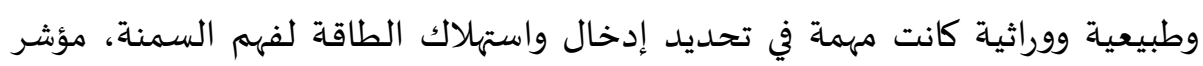


الكمية الجسمية BMI المرتفع وضغط الدم الشرياني باعتباره المريض الرئيسي الجماعي غير المعدي.

إلى جانب التدخين والضغط وتناول المسكرات بشكل مفرط ونشاط الجسم غير

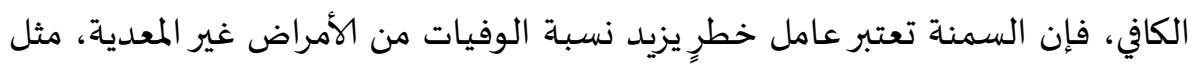

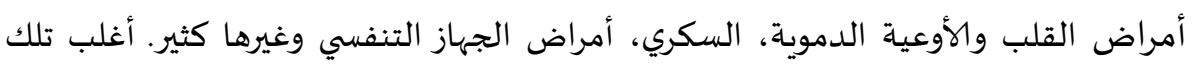

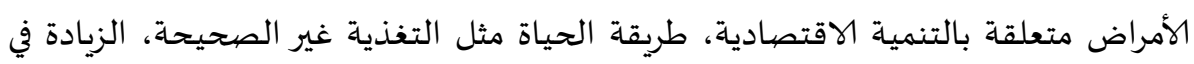

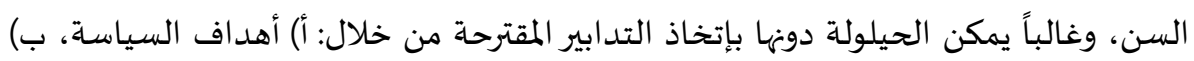

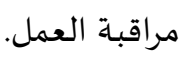

الكلمات الرئيسـة: السمنة، ضغط الدم، أمراض القلب والأوعية الدموية، مؤشر الكمية الجسمية (Body mass index) 